\title{
The role of oestrogen and progesterone receptors in gigantomastia
}

\author{
Anna Kasielska-Trojan ${ }^{1}$, Marian Danilewicz², Jerzy Strużyna ${ }^{3}$, Magdalena Bugaj, \\ Bogusław Antoszewski ${ }^{1}$
}

\begin{abstract}
${ }^{1}$ Plastic, Reconstructive and Aesthetic Surgery Clinic, Medical University of Lodz, Lodz, Poland

${ }^{2}$ Department of Pathology, Medical University of Lodz, Lodz, Poland

${ }^{3}$ Eastern Centre of the Burns Treatment and Reconstructive Surgery, tęczna, Poland
\end{abstract}

Submitted: 4 December 2018; Accepted: 22 April 2019

Online publication: 26 September 2019

Arch Med Sci 2022; 18 (4): 1016-1020

DOI: https://doi.org/10.5114/aoms.2019.88280

Copyright $\odot 2019$ Termedia \& Banach

\section{Abstract}

Introduction: Gigantomastia is a rare condition characterised by excessive breast growth. The pathophysiology of mammary enlargement varies depending on the type of gigantomastia: gestational, juvenile virginal, or idiopathic. The study aimed at examining the receptor status (oestrogen receptor $\alpha$ $(E R \alpha)$ and progesterone receptor (PR)) of breast tissue in adult women with juvenile or idiopathic gigantomastia.

Material and methods: The study involved 70 women who underwent breast reduction due to juvenile or idiopathic gigantomastia. Control breast specimens were obtained from 18 female cadavers. ER $\alpha$ and PR expressions were detected immunohistochemically in breast gland samples.

Results: Categorised and uncategorised ER $\alpha$ and PR expression did not differ between women with gigantomastia and control women. It was found that in both groups weak (0-30\%) ER $\alpha$ and PR expression was the most common. Analysis of categorised data also did not reveal any significant correlations between ER $\alpha$ or PR and the women's age: for the whole group: $p=0.795(\mathrm{ER} \alpha), p=0.207(\mathrm{PR})$, for women with gigantomastia: $p=0.934$ $(\mathrm{ER} \alpha), p=0.43(\mathrm{PR})$, and for control women: $p=0.638(\mathrm{ER} \alpha), p=0.805(\mathrm{PR})$. Conclusions: Gigantomastia is not caused by increased expression of ER $\alpha$ and PR. Analysing abnormal sensitivity of these receptors to hormones may be crucial in establishing the increased risk of breast cancer in women with gigantomastia.

Key words: oestrogen receptor, progesterone receptor, gigantomastia.

\section{Introduction}

Gigantomastia is a rare condition characterised by excessive breast growth. It can be physically disabling for a patient due to mastalgia, neck and back pain, headaches, trophic lesions of the breast skin with ulceration and infection, difficulty finding well-fitting clothes, and limited ability to exercise. It can also cause psychosocial problems, such as depression and sociophobia, related to the cosmetic defect. To date, there has not been a universal classification or definition for gigantomastia. It used to be defined as breast enlargement that requires reduction of over $1500 \mathrm{~g}$ per breast; however, currently physical and psychological symptoms seem to be the major criteria for the diagnosis rather than the volume of excess breast tissue that needs to be removed [1-5].

\author{
Corresponding author: \\ Anna Kasielska-Trojan MD PhD \\ Plastic, Reconstructive \\ and Aesthetic Surgery Clinic \\ Medical University of Lodz \\ 22 Kopcinskiego St \\ Lodz, Poland \\ E-mail: annakas@toya.net.pl
}


The pathophysiology of mammary enlargement varies depending on the type of gigantomastia. It can be the result of hormonal disturbances and changes due to some disorders or physiological conditions like pregnancy - gestational gigantomastia (GG) [6-8]. The aetiology of GG remains elusive. Although some theories have been proposed, including excessive production of oestrogen or prolactin, hormone receptor sensitivity, or underlying autoimmune disease triggered by pregnancy, none was scientifically verified $[9,10]$. It was also hypothesised, that GG in women with normal hormone levels (the most common type) may be explained by increased hormonal sensitivity in the target organ, but this theory was not verified [11-13].

The second most common type of gigantomastia is juvenile virginal enlargement of the breast, which can be seen as early as in late childhood and is often present between the ages of 11 and 14 years $[1,14]$. Some authors also identify spontaneous idiopathic gigantomastia, defined as breast enlargement not related to puberty or pregnancy $[15,16]$. These are, however, case-reports, which makes it difficult to recognise this type of gigantomastia. Moreover, recent case-studies show that the reason for such a presentation may be pseudoangiomatous stromal hyperplasia (PASH) $[17,18]$.

The aim of this research was to examine the receptor status (oestrogen receptor $\alpha(E R \alpha)$ and progesterone receptor (PR)) of breast tissue in adult women with juvenile or idiopathic gigantomastia.

\section{Material and methods}

\section{Participants}

The study involved 70 patients who underwent breast reduction due to juvenile or idiopathic gigantomastia in two plastic surgery centres located in different regions of the country (27 women from one centre and 43 from the other). The average age of the studied individuals was 39.9 \pm 10.35 years (range: $19-59$ ). All patients qualified for surgical treatment had undergone endocrine examinations, and a detailed medical interview had also been conducted to exclude other possible reasons for breast enlargement. Breast ultrasonography or mammography examinations were performed. All procedures were carried out because of therapeutic indications and were financed by the National Health Fund. To meet these criteria patients provided referrals from a neurosurgeon, neurologist, or orthopaedist confirming a cervical or spine disorder due to heavy breasts. Exclusion criteria included: any hormonal disturbances or treatment (current or past, excluding contraceptives), obesity (BMI > $30 \mathrm{~kg} / \mathrm{m}^{2}$ ), pregnancy-related gigantomastia, operation disabling general state of health, any abnormalities in breast imaging, history of breast malignancy, no clinical physical symptoms of gigantomastia, and aesthetic reasons. Surgical techniques involved breast reduction with nipple-areola complex transposition with upper, lower, or upper-medial pedicles or as a free graft. Histopathological examinations of removed tissues were done routinely. Tissue samples for the examination of receptors were obtained after a histopathological analysis. $E R \alpha$ and PR expressions were detected immunohistochemically. This examination was done in the case of all samples from both clinics, in one centre, by one histopathology specialist.

The control breast samples were obtained from 18 female cadavers (mean age \pm SD: $66.3 \pm 10.52$ years) on whom obligatory post-mortem examinations were performed due to national law. A sample of breast gland was harvested by a histopathology specialist, in addition to the routine procedure, for the purpose of the study. The specialist excluded women who had a history of breast cancer or had macromastia.

The protocol for the study was approved by the Local Ethics Committee (of the Medical University of Lodz, RNN/191/17/KE).

\section{Immunohistochemistry}

Immunohistochemical staining for ER $\alpha$ and PR was performed on $3 \mu \mathrm{m}$ sections from archive paraffin blocks. The sections were deparaffinised and antigen retrieval was performed using DakoTPlink. The slides were then loaded on a Dako Autostainer Plus (the elements of the automatic Dako line for standardised immunohistochemistry) and incubated with primary "ready to use" anti-ER $\alpha$ and anti-PR (PR clone PgR636 binding with PR-A and PR-B) antibodies according to the manufacturer's instructions. As a positive control, the sections from ER- $\alpha$ and PR-positive breast carcinoma were used. In each case two slides were evaluated and 200 nuclei were counted. The nuclear immunoexpression of ER $\alpha$ and PR was observed in glandular epithelium of breast tissue.

\section{Oestrogen and progesterone receptor concentration measurements}

$E R \alpha$ - and PR-positive nuclei were evaluated using a computer image analysis system consisting of a PC computer equipped with a Pentagram graphic tablet, Indeo Fast card (frame grabber, truecolour, real-time), produced by Indeo (Taiwan), and a Panasonic colour TV camera (Japan) coupled with Carl Zeiss microscope (Germany). This system was programmed (MultiScan 18.03 software, produced by Computer Scanning Systems, Poland) to calculate the number of objects (semiautomatic function) (Figures 1 and 2). The results were pre- 


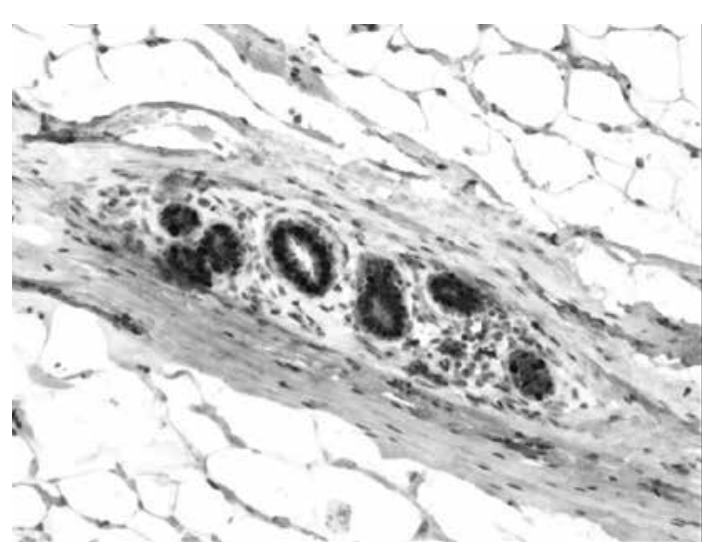

Figure 1. Immunohistochemistry. Expression of oestrogen receptor $\alpha$ in nuclei of glandular epithelium. Magnification $100 \times$

sented as the percentage of positive nuclei from all nuclei counted in the glandular epithelium.

\section{Statistical analysis}

An analysis was conducted in the aspect of the differences in the ER $\alpha$ and PR expression in breast glands in women with gigantomastia and in the control glands. The normality of distribution of the tested variables was examined using the Kolmogorov-Smirnov test. Due to the lack of normality of distribution of data concerning ER $\alpha$ and PR expression, the non-parametric Mann-Whitney test was used. To examine correlations between $E R \alpha$ and PR expression and patients' age, Spearman's correlation coefficients were calculated.

For statistical purposes we categorised ER $\alpha$ and PR expression as weak (0-30\%), moderate

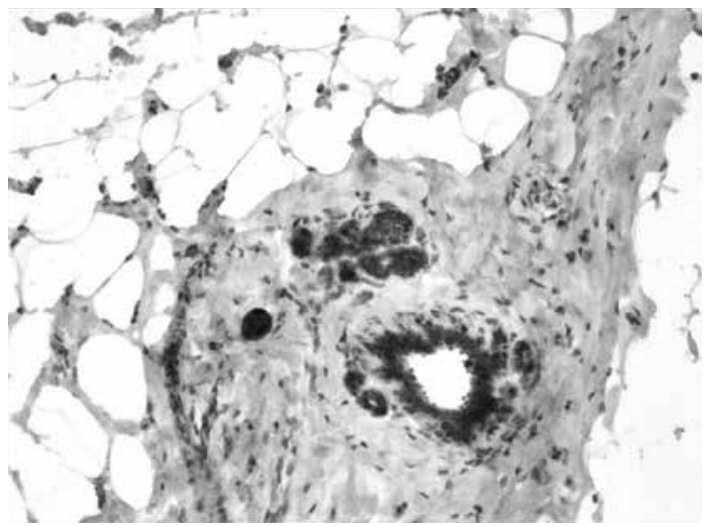

Figure 2. Immunohistochemistry. Expression of progesterone receptor in nuclei of glandular epithelium. Magnification 100x

(31-60\%), high (61-90\%), or very high (91-100\%) and compared the categorised data.

\section{Results}

All glands were subjected to a routine histopathological examination, which did not reveal any cases of tumours. Categorised and uncategorised ER $\alpha$ and PR expression did not differ between women with gigantomastia and control women. It was found that in both groups weak (0-30\%) ER $\alpha$ and PR expression was the most common (Table I). Statistical analysis did not reveal any correlations between ER $\alpha$ and PR expression and the age of the examined women (Table II). Analysis of categorised data also did not reveal any significant correlations between ER $\alpha$ or PR and the women's age - for the whole group: $p=0.795$ (ER $\alpha)$, $p=0.207$ (PR), for women with gigantomastia:

Table I. Categorised and uncategorised oestrogen receptor $\alpha(E R \alpha)$ and PR expression in women with gigantomastia and control women

\begin{tabular}{|c|c|c|c|c|c|c|c|}
\hline $\begin{array}{l}\text { ER } \alpha \\
\text { expression }\end{array}$ & $\begin{array}{c}\mathrm{G} \\
(n=70)\end{array}$ & $\begin{array}{c}\mathrm{W} \\
(n=18)\end{array}$ & Test/p & $\begin{array}{c}\text { PR } \\
\text { expression }\end{array}$ & $\begin{array}{c}\mathrm{G} \\
(n=70)\end{array}$ & $\begin{array}{c}\mathrm{W} \\
(n=18)\end{array}$ & Test/p \\
\hline $0-30 \%$ & 46 & 10 & \multirow{4}{*}{$\begin{array}{l}\chi^{2}=4.736 \\
p=0.192\end{array}$} & $0-30 \%$ & 48 & 17 & \multirow{4}{*}{$\begin{array}{c}\chi^{2}=5.059 \\
p=0.08\end{array}$} \\
\hline $31-60 \%$ & 16 & 8 & & $31-60 \%$ & 16 & 1 & \\
\hline $61-90 \%$ & 7 & 0 & & $61-90 \%$ & 6 & 0 & \\
\hline $91-100 \%$ & 1 & 0 & & $91-100 \%$ & 0 & 0 & \\
\hline $\begin{array}{l}\text { The mean } \\
\text { (SD) }\end{array}$ & $\begin{array}{c}31 \\
(23.3)\end{array}$ & $\begin{array}{c}32.78 \\
(8.4)\end{array}$ & $\begin{array}{c}M W=492.5 \\
p=0.156\end{array}$ & $\begin{array}{c}\text { The mean } \\
\text { (SD) }\end{array}$ & $\begin{array}{l}28.21 \\
(21.3)\end{array}$ & $\begin{array}{c}23.89 \\
(8.3)\end{array}$ & $\begin{array}{c}M W=600.5 \\
p=0.762\end{array}$ \\
\hline
\end{tabular}

MW - Mann-Whitney test, G - gigantomastia, W-control women.

Table II. Oestrogen receptor $\alpha(E R \alpha)$ and PR expression correlation with age in women with gigantomastia and control women

\begin{tabular}{|c|c|c|c|c|c|c|c|c|c|}
\hline \multirow[t]{2}{*}{ Variable } & \multicolumn{3}{|c|}{$\mathrm{G}$ and $\mathrm{W}(n=88)$} & \multicolumn{3}{|c|}{$\mathrm{G}(n=70)$} & \multicolumn{3}{|c|}{$\mathrm{W}(n=18)$} \\
\hline & $r$ & $t$ & $p$ & $r$ & $t$ & $p$ & $r$ & $t$ & $p$ \\
\hline ER $\alpha$ vs. age & 0.191 & 1.800 & 0.075 & 0.143 & 1.198 & 0.235 & 0.116 & 0.467 & 0.647 \\
\hline PR vs. age & 0.066 & 0.61 & 0.544 & 0.082 & 0.675 & 0.502 & 0.028 & 0.113 & 0.911 \\
\hline
\end{tabular}

$r$-Spearman's correlation coefficient, $G$ - gigantomastia, $W$ - control women. 
$p=0.934(\mathrm{ER} \alpha), p=0.43(\mathrm{PR})$, and for control women: $p=0.638(\mathrm{ER} \alpha), p=0.805$ (PR).

\section{Discussion}

The aetiology of gigantomastia is unknown, and exploration of this issue seems to be important because it could help to answer the question about the possible risk of breast cancer in these women. However, it has not been established if gigantomastia increases this risk and if women with this condition should be subjected to any additional or more frequent screenings for breast cancer. Kusano et al. found that for lean women, larger breast size was associated with a higher risk of breast cancer, and Eriksson et al. showed that two single nucleotide polymorphisms, which have previously been associated with breast cancer risk, are also associated with breast size [19, 20]. Other studies have suggested that expression levels of $E R \alpha, P R$, insulin-like growth factor 1 receptor (IGF-1R), and Ki67 in cancer-free breast tissue may be associated with subsequent breast cancer risk [21-25].

Only a few studies concerning the possible aetiology of gigantomastia can be found in the literature, and their results are inconsistent. Jabs et al. reported negative expression of oestrogen receptors in the breast tissue of all examined women $(n=25)$ with breast hypertrophy [26], while Sun et al. reported that oestrogen receptor status was different in patients with breast hypertrophy and micromastia patients [27]. The aim of this study was to determine the expression of $E R \alpha$ and $P R$ in breast tissue obtained from women with pubertal and idiopathic gigantomastia. The results revealed that $E R \alpha$ and $P R$ expressions in the glands of these women did not differ from the receptor expressions in control women. Although the mean age of the control group was higher than the age of the examined women, statistical analysis did not reveal a correlation between age and receptor expression.

The presented study has some limitations. Although the number of cases may seem to be small, juvenile and/or idiopathic gigantomastia is a rare condition, and the inclusion criteria were rigorous because we excluded obese women and those with any possible causative factors of breast enlargement. Another important limitation is the fact that the analysed groups differed in age (preand post-menopause women), which might have affected the results. However, we did not find correlation between ER $\alpha$ and PR and the age, which provided a rationale for such analysis.

The results of this study appeared to be different from our findings of idiopathic gynaecomastia in men, because we found out that men with idiopathic gynaecomastia present primary "overexpression" of ER and PR, which may cause idiopathic breast enlargement in this group [28]. In women with gigantomastia the cause of breast enlargement seems to be different and not associated with $E R \alpha$ and PR overexpression in breast glands. Also, this condition was not related to hormonal abnormalities or hormonal drug intake because such women were excluded from the studied group. Moreover, all participants had routine histopathological examination of the resected breast tissue performed, and no pathological findings were detected. Other condition that may present as isolated macromastia - excess aromatase syndrome - is a very rare genetic syndrome, and usually some other clinical manifestations are present. On the basis of the conducted studies, it can be presumed that ER $\alpha$ and/or PR in women with gigantomastia may be "oversensitive" to hormones, or there are other receptor and hormone anomalies responsible for breast enlargement (i.e. growth hormone, cytokines). Additionally, apart from the mammary gland, the major component of the enlarged breast is fatty tissue, which seems to be hypertrophic or hyperplastic, so further studies concerning the aetiology of gigantomastia could focus on the cause and type of fat accumulation in breasts.

In conclusion, hypothesis concerning ER $\alpha$ and PR oversensitivity in women with gigantomastia should be verified by looking for specific gene polymorphisms that could cause this condition. Moreover, analysing abnormal sensitivity of receptors to hormones may also be crucial in establishing the increased risk of breast cancer in women with gigantomastia, because receptor polymorphisms causing receptor hypersensitivity related to increased breast cancer risk were detected [29-31].

\section{Conflict of interest}

The authors declare no conflict of interest.

\section{References}

1. Dancey A, Khan M, Dawson J, Peart F. Gigantomastia - a classification and review of the literature. J Plast Reconstr Aesthet Surg 2008; 61: 493-502.

2. Taylor CJ, Chester DL. Bilateral breast reduction surgery in elderly women: a retrospective review of outcomes. J Plast Reconstr Aesthet Surg 2012; 65: 304-11.

3. Netscher DT, Meade RA, Goodman CM, et al. Physical and psychosocial symptoms among 88 volunteer subjects compared to patients seeking plastic surgery procedures to the breast. Plast Reconstr Surg 2000; 105: 2366-73.

4. Kerrigan CL, Collins ED, Striplin D, et al. The health burden of breast hypertrophy. Plast Reconstr Surg 2001; 108: 1591-9.

5. Blomqvist L, Eriksson A, Brandberg Y. Reduction mammaplasty provides long-term improvement in health 
status and quality of life. Plast Reconstr Surg 2000; 106 991-7.

6. Swelstad MR, Swelstad BB, Rao VK, Gutowski KA. Management of gestational gigantomastia. Plast Reconstr Surg 2006; 118: 840-8.

7. Ezem BU, Osuagwu CC, Opara KA. Gestational gigantomastia with complete resolution in a Nigerian woman. BMJ Case Reports 2011: pii: bcr0120102632.

8. Antevski B, Jovkovski O, Filipovski V, Banev S. Extreme gigantomastia in pregnancy: case report - my experience with two cases in last 5 years. Arch Gynecol Obstet 2011; 284: 575-8.

9. Leis SN, Palmer B, Ostberg G. Gravid macromastia. Case report. Scand J Plast Reconstr Surg 1974; 8: 247-9.

10. Jido TA, Mohamed AZ, Alhasan SU. Gigantomastia complicating pregnancy: a case report. Niger J Med 2006; 15: 167-9.

11. Wølner-Hanssen P, Palmer B, Sjöberg NO, Astedt B. Gigantomastia. Acta Obstet Gynecol Scand 1981; 60: 525-7.

12. Agarwal N, Kriplani A, Gupta A, Bhatla N. Management of gigantomastia complicating pregnancy. A case report. J Reprod Med 2002; 47: 871-4.

13. Stavrides S, Hacking A, Tiltman A, Dent DM. Gigantomastia in pregnancy. Br J Surg 1987; 74: 585-6.

14. Mathes SJ (ed.). Plastic Surgery. Vol 6. Elsevier, Philadelphia 2006; 539-84.

15. Skillman J, Beechey-Newman N, Hamed H. Gigantomastia unrelated to pregnancy or puberty: a case report. Breast 2002; 11: 179-80.

16. Cho MJ, Yang JH, Choi HG, Kim WS, Yu YB, Park KS An idiopathic gigantomastia. Ann Surg Treat Res 2015; 88: 166-9.

17. Oppenheimer AJ, Oppenheimer DC, Fiala TG, Noori S. Pseudoangiomatous stromal hyperplasia: a rare cause of idiopathic gigantomastia. Plast Reconstr Surg Glob Open 2016; 4: e593.

18. Roy M, Lee J, Aldekhayel S, Dionisopoulos T. Pseudoangiomatous stromal hyperplasia: a rare cause of idiopathic gigantomastia. Plast Reconstr Surg Glob Open 2015; 3: e501.

19. Kusano AS, Trichopoulos D, Terry KL, Chen WY, Willett WC, Michels KB. A prospective study of breast size and premenopausal breast cancer incidence. Int J Cancer 2006; 118: 2031-4.

20. Eriksson N, Benton GM, Do CB, et al. Genetic variants associated with breast size also influence breast cancer risk. BMC Medical Genetics 2012; 13: 53.

21. Santisteban M, Reynolds C, Barr Fritcher EG, et al. Ki67: a time-varying biomarker of risk of breast cancer in atypical hyperplasia. Breast Cancer Res Treat 2010; 121:431-7.

22. Khan SA, Rogers MA, Obando JA, Tamsen A. Estrogen receptor expression of benign breast epithelium and its association with breast cancer. Cancer Res 1994; 54: 993-7.

23. Lydon JP, Ge G, Kittrell FS, Medina D, O'Malley BW. Murine mammary gland carcinogenesis is critically dependent on progesterone receptor function. Cancer Res 1999; 59: 4276-84.

24. Oh $\mathrm{H}$, Eliassen $A H$, Wang $M$, et al. Expression of estrogen receptor, progesterone receptor, and Ki67 in normal breast tissue in relation to subsequent risk of breast cancer. NPJ Breast Cancer 2016; 2: pii: 16032.

25. Tamimi RM, Colditz GA, Wang Y, et al. Expression of IGF1R in normal breast tissue and subsequent risk of breast cancer. Breast Cancer Res Treat 2011; 128: 243-50.
26. Jabs AD, Frantz AG, Smith-Vaniz A, et al. Mammary hypertrophy is not associated with increased estrogen receptors. Plast Reconstr Surg 1990; 86: 64-6.

27. Sun J, Qiao Q, Qi K. The difference in estrogen receptor protein level between breast hypertrophy and micromastia. Plast Reconstr Surg 2004; 113: 2241-2.

28. Kasielska-Trojan A, Danilewicz M, Antoszewski B. The role of expression of oestrogen and progesterone receptors in idiopathic gynecomastia aetiology. Breast J 2019; 25 331-3.

29. Hu X, Jiang L, Tang C, et al. Association of three single nucleotide polymorphisms of ESR1 with breast cancer susceptibility: a meta-analysis J Biomed Res 2017; 31:213-25.

30. Li T, Zhao J, Yang J, et al. A meta-analysis of the association between ESR1 genetic variants and the risk of breast cancer. PLoS One 2016; 11: e0153314.

31. Gallegos-Arreola MP, Figuera LE, Flores-Ramos LG, PueblaPérez AM, Zúñiga-González GM. Association of the Alu insertion polymorphism in the progesterone receptor gene with breast cancer in a Mexican population. Arch Med Sci 2015; 11: 551-60. 